\title{
Author's Reply to: Virtual vs Online: Insight From Medical Students. Comment on "Effectiveness of Virtual Medical Teaching During the COVID-19 Crisis: Systematic Review"
}

\author{
Robyn-Jenia Wilcha \\ Faculty of Biology, Medicine and Health, University of Manchester, Manchester, United Kingdom
}

Corresponding Author:

Robyn-Jenia Wilcha

Faculty of Biology, Medicine and Health

University of Manchester

Oxford Road

Manchester, M13 9PL

United Kingdom

Phone: 44 (0)161 3060211

Email: robynwilcha05@gmail.com

\section{Related Articles:}

Comment on: https://mededu.jmir.org/2021/2/e27020/

Comment on: https://mededu.jmir.org/2020/2/e20963/

(JMIR Med Educ 2021;7(2):e29335) doi: 10.2196/29335

\section{KEYWORDS}

virtual teaching; medical student; medical education; COVID-19; review; search term; virus; pandemic; quarantine

I am grateful for the opportunity to respond to the issues raised in the letter by Kaini and Motie [1] and to clarify aspects of my methodology in relation to these concerns. I would also like to thank these fifth-year medical students at University College London (UCL) for their interest in my paper [2] and for taking the time to express their considerations.

Potential concerns were raised in regard to limitations of the original review [2]. Foremost, I appreciate that my colleagues at UCL understand the novel nature of the study and the emerging essence of literature at the time of writing. I agree that the paper written by Nik-Ahmad-Ziki et al [3] raises further excellent points reviewing the psychological impacts of technical triumphs and difficulties on both clinicians and students, and likewise, the paper by Singh et al [4] reflects important disadvantages to virtual medical education. As acknowledged by my colleagues, studies with small sample sizes were included in my original review; this was noted in the Discussion section of my paper as a limitation secondary to the developing nature of the COVID-19 pandemic.

However, the primary objective of this study [2] was to provide a brief review of the effectiveness of virtual medical education at the time of an evolving global pandemic, and I believe that the concerns raised by Kaini and Motie [1] had minimal impact in accomplishing this objective. Considered by my colleagues is the impact of student mental health in line with virtual teaching; the views of 7 further authors were outlined in my paper, documenting findings similar to Nik-Ahmad-Ziki's study [3] of decreased motivation, engagement, and lack of support [5]. As a result, I believe it is unlikely that the loss of Nik-Ahmad-Ziki's study [3] would have had any deleterious effects in addressing the primary purpose of my study. Moreover, the timeframe of articles to meet my inclusion criteria was between the dates of February to June 2020. The paper by Singh et al [4] was published in completed format in July 2020, which falls outside these dates [3]. However, the paper by Kaur et al [6], included in my review, has a large sample size of 983 students and concluded similar findings to Singh et al [4], stating that students found virtual teaching unsatisfactory in comparison to face-to-face teaching due to difficulties in supporting individual learning needs, interaction levels, convenience, and balancing practical/theoretical knowledge [5].

It is apparent that we share similar interests in the development of medical education, especially due to our shared first-hand experience. It is likely that advancements in virtual medical education will revolutionize the field of medical sciences, and the COVID-19 pandemic presents a unique opportunity to explore new and innovative teaching techniques to shape the nature of medical education. Ultimately, I agree with my colleagues at UCL that more research is needed to fully understand the short- and long-term impacts of virtual teaching on future doctors. 


\section{Conflicts of Interest}

None declared.

\section{References}

1. Kaini S, Motie LZ. Virtual vs Online: Insight From Medical Students. Comment on "Effectiveness of Virtual Medical Teaching During the COVID-19 Crisis: Systematic Review”. JMIR Med Educ 2021 May 14;7(2):e27020 [FREE Full text] [doi: $\underline{10.2196 / 27020]}$

2. Wilcha RJ. Effectiveness of Virtual Medical Teaching During the COVID-19 Crisis: Systematic Review. JMIR Med Educ 2020 Nov 18;6(2):e20963 [FREE Full text] [doi: 10.2196/20963] [Medline: $\underline{\text { 33106227] }}$

3. Nik-Ahmad-Zuky NL, Baharuddin KA, Abdul Rahim AF. Online Clinical Teaching and Learning for Medical Undergraduates during the COVID-19 Pandemic: The Universiti Sains Malaysia (USM) Experience. EIMJ 2020 Jun 30;12(2):75-80. [doi: 10.21315/eimj2020.12.2.8]

4. Singh K, Srivastav S, Bhardwaj A, Dixit A, Misra S. Medical Education During the COVID-19 Pandemic: A Single Institution Experience. Indian Pediatr 2020 May 4;57(7):678-679. [doi: 10.1007/s13312-020-1899-2]

5. Longhurst GJ, Stone DM, Dulohery K, Scully D, Campbell T, Smith CF. Strength, Weakness, Opportunity, Threat (SWOT) Analysis of the Adaptations to Anatomical Education in the United Kingdom and Republic of Ireland in Response to the Covid-19 Pandemic. Anat Sci Educ 2020 May;13(3):301-311 [FREE Full text] [doi: 10.1002/ase.1967] [Medline: 32306550]

6. Kaur N, Dwivedi D, Arora J, Gandhi A. Study of the effectiveness of e-learning to conventional teaching in medical undergraduates amid COVID-19 pandemic. Natl J Physiol Pharm Pharmacol 2020;10(7):563-567 [FREE Full text] [doi: 10.5455/njppp.2020.10.04096202028042020]

\section{Abbreviations}

UCL: University College London

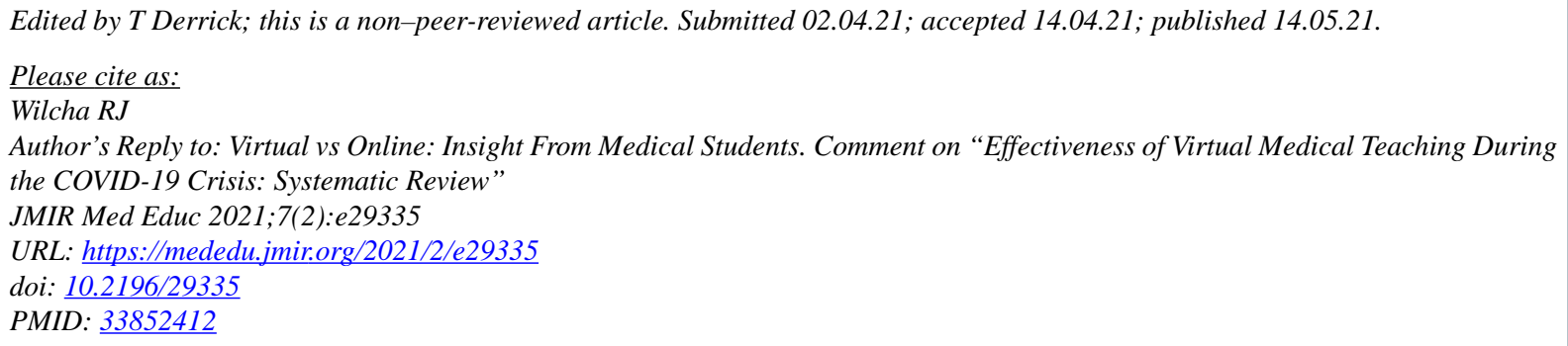

CRobyn-Jenia Wilcha. Originally published in JMIR Medical Education (https://mededu.jmir.org), 14.05.2021. This is an open-access article distributed under the terms of the Creative Commons Attribution License (https://creativecommons.org/licenses/by/4.0/), which permits unrestricted use, distribution, and reproduction in any medium, provided the original work, first published in JMIR Medical Education, is properly cited. The complete bibliographic information, a link to the original publication on https://mededu.jmir.org/, as well as this copyright and license information must be included. 